\title{
Development Strategy Analysis of Tourism Site and Attraction in Lasiana Beach of Kupang City
}

\author{
Agustino Lukas Fischer Conterius ${ }^{1}$, Merlin Luisa Malelak ${ }^{1}$ \\ \{agustino.conterius@gmail.com, merlinmalelak0305@gmail.com\} \\ Politeknik Negeri Kupang, Indonesia ${ }^{1}$
}

\begin{abstract}
Lasiana Beach is a particular tourism site located in Lasiana Sub District, Kelapa Lima District, Kupang City. The lack of development and poor management renders the site to be unattractive to visitors. Minimum facility, roaming wild animals, rubbish and animal waste do tarnish the exoticism of Lasiana Beach. Moreover, there is a recent threat of wandering crocodiles, making visitors reluctant to visit Lasiana Beach. This research aims to: (1) analyze internal (strengths and weaknesses) and external (opportunities and threats) factors in the management of the tourism site and attraction of Lasiana Beach through an SWOT analysis, and (2) analyze the strategy which can be applicable to supportthe tourism site and attraction of Lasiana Beach through the SWOT. This research applies a qualitative method with a descriptive approach. The SWOT analysis matrix is used to analyze the strengths, weaknesses, opportunities and threats, method, and furthermore to craft a development strategy for the tourism site and attraction of Lasiana Beach. Data collection utilizes in-depth interviews, documentation, literature study, and observation methods.
\end{abstract}

Keywords: Development Strategy, SWOT Analysis, Lasiana Beach.

\section{INTRODUCTION}

Tourism is considered important and attractive to everyone, therefore it needs to be developed according to the charm of tourism. An area can become a tourist destination if the area can be developed into a tourist attraction. Good tourism attractions must be able to bring as many tourists as possible, keep them in the attractions for longer periods and provide satisfaction to tourists [1].

Kupang City as the capital of East Nusa Tenggara Province has a variety of potentials and tourist attractions both natural tourist attractions (beaches, natural caves, mangrove forests, springs), cultural tourism attractions (archeological sites, king's houses, fortresses, museums, sasando craft houses), historical tourist attractions (Japanese caves, World War II bunkers, Australian cannons, Japanese monuments) and other tourist attractions [2]. One tourist attraction that is quite well known and has quite potential prospects to be managed and developed is Lasiana Beach. This beach is located in Lasiana Village, Kelapa Lima District, Kupang City, and is $12 \mathrm{~km}$ from the city center, and can be reached by four-wheeled or two-wheeled vehicles.

Lasiana Beach is one of the marine tourism assets in the city of Kupang that has a high attraction with an atmosphere and scenery that is still beautiful because it is directly located in Kupang Bay. This beach is a favorite tourist attraction as well as a mainstay 
tourist attraction that is expected to increase the number of tourist visits, both local tourists, domestic tourists, and foreign tourists in the city of Kupang each year.

There are several problems that are quite crucial in the management and development of Lasiana Beach, including; minimal tourist attractions, there are still some facilities that are damaged and unfit for use, wild animals roam around this beach, garbage and animal feces contained in this beach area, breakwater dikes that cause mud deposition along the lips of Lasiana Beach, and threats the existence of crocodiles which increasingly makes tourists reluctant to visit this beach. This condition is indeed ironic considering the potential of Lasiana Beach which is very promising, but has not been managed optimally and professionally.

This should be a major concern for the Provincial Government of East Nusa Tenggara through the Department of Tourism and Creative Economy as the manager of Lasiana Beach. To that end, various changes that occur must be addressed and anticipated by the NTT Provincial Government by implementing an effective strategy by maximizing strengths, weaknesses, opportunities and threats in the management and development of Lasiana Beach. The development strategy is also expected to advance Lasiana Beach tourism object into a favorite tourist attraction that is crowded by tourists and can have a positive impact on local government income, increase community welfare, promote community culture, preserve nature, the environment and other resources at tourist sites Lasiana Beach and the surrounding area.

The formulation of the problem to be investigated is; (1) what are internal factors (strengths and weaknesses) and external factors (opportunities and threats) contained in the management of tourist objects and attractions of Lasiana Beach? (2) What strategies need to be applied in supporting the management of Lasiana Beach objects and tourist attractions? Based on the background and formulation of the problem being analyzed, this research was conducted with the aim; (1) to analyze internal factors (strengths and weaknesses) and external factors (opportunities and threats) in the management of Lasiana Beach objects and tourist attractions by using SWOT analysis and (2) to analyze strategies that need to be applied in supporting the management of objects and attractions Lasiana Beach tourism using SWOT analysis.

\section{LITERATURE REVIEW}

Tourism is a variety of tourism activities and is supported by various facilities and services provided by the community, entrepreneurs, government, and regional governments [3]. To support tourism activities, an attractive tourist attraction is needed. Tourist attraction is anything that has a uniqueness, beauty, and value in the form of diversity of natural, cultural, and man-made diversity that is the target or destination of tourist visits [4].

A tourist destination must have an attractive tourist attraction so that it is visited by tourists. The more crowded a tourist attraction, the more it will encourage the development of regions / countries where the tourist attraction is located. A tourist destination must have its own attraction to bring tourists and must have 3 supporting aspects, namely; (1) tourist attractions, (2) amenities, and (3) accessibility. There is a close relationship between the tourist attraction and the tourism industry [5].

As two sides of a coin that cannot be separated, the development of objects and tourist attraction will have implications for the advancement of the tourism industry in the area that can encourage increased public welfare, income distribution, income from fees 
and taxes which will all have implications for improving the regional economy / country where the tourist attraction is located [6].

The tourism industry is a group of business fields that produce various types of goods and services needed by everyone (tourists) who carry out tourism activities [7]. This tourism industry will develop, if the objects and tourist attractions that are in an area also develop. So that it takes a competent strategy in the management of tourist objects and attractions so that economic rotation and growth continues. Strategy is a statement that directs how each individual can work together in an organization, in an effort to achieve the goals and objectives of the organization [8]. With the right planning and implementation of strategies, a tourist attraction will certainly increasingly develop, and can encourage the development of the tourism industry and have implications for economic growth.

\section{METHOD}

This type of research is a descriptive study with a qualitative approach, namely research that is based on the philosophy of postpositivism and is used to examine the conditions of natural objects, where researchers as a key instrument by sampling data sources conducted by purposive and snowball [9]. Data collected in the form of oral and written information obtained through observation, in-depth interviews, documentation and library data. As for the informants in this study are the parties directly related to the tourist attraction of Kupang Lasiana Beach, namely the Head of the NTT Province Tourism and Creative Economy Office, the Head of the Lasiana Beach Tourism Destination Management, the traders selling at Lasiana Beach and the tourists visiting the Lasiana Kupang Beach. The data source in this study is primary data obtained through direct interviews with informants and observations on Lasiana Beach, Kupang. Secondary data in this study were obtained from the NTT Province Office of Tourism and Creative Economy, Lasiana Coast UPTD Office, as well as other literature related to research issues such as from books, scientific papers, and journals on strategies for developing tourist objects and attractions.

Data collected in this study were analyzed with descriptive analysis methods to explain or describe phenomena that are related to the problem under study, as well as to answer the driving factors and obstacles in the development of objects and tourist attractions in Kupang's Lasiana Beach. To answer the strategy of developing objects and attractions of Lasiana Beach, SWOT analysis is used, which stands for strengths and weaknesses which are the internal environment as well as opportunities and threats which are the external environment faced by an certain companies or organizations [10].

The purpose of the SWOT analysis formulation is to classify problems and facilitate a strategic approach, in the framework of the formulation of a strategy for developing objects and tourist attractions in Kupang's Lasiana Beach. After the development strategy formulation is analyzed and alternative strategies are found, the next step is to choose and recommend relevant strategies in the effort to develop objects and tourist attractions in Kupang's Lasiana Beach. These stages can be seen in the chart below: 


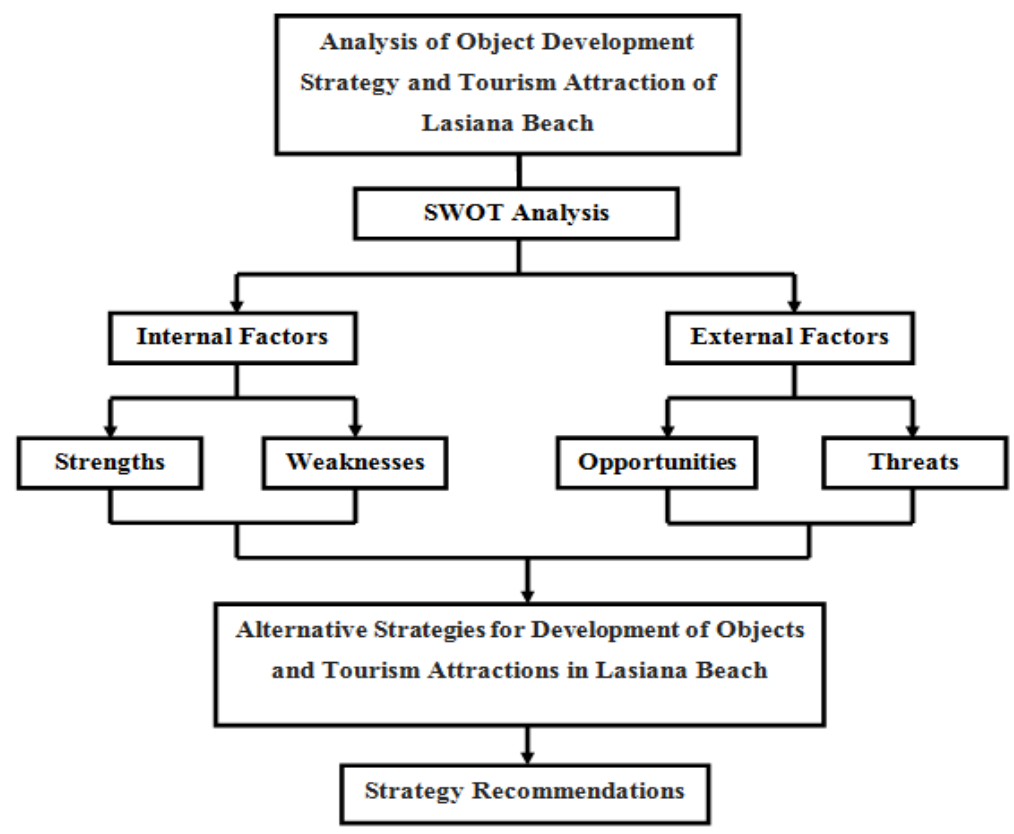

Fig. 1. Research Flow Chart

\section{RESULTS AND DISCUSSION}

4.1. Identification of strengths, weaknesses, opportunities and threats in the management and development of Lasiana Beach.

\section{Internal Factors (Strengths and Weaknesses)}

(Strengths)

1. The Beauty of Natural Panorama

Lasiana Beach is located in the bay of Kupang and has a very beautiful natural panorama, plus the combination of brownish white sand and blue sea adds to the beauty of Lasiana Beach.

2. There are many palm trees

Lasiana Beach has an area of 3.5 hectares and is decorated by approximately 65 coconut trees and 230 palm trees that line the white sand of this beach. This is what makes Lasiana beach unique and different from other beaches, because along the beach is decorated by a row of palm trees that are neatly lined and charming.

3. The location is not far from the city center and easy to access

The location of Lasiana Beach is not far from the center of Kupang, which is only about $12 \mathrm{~km}$, and can be accessed easily using private vehicles or public transportation.

4. Cultural Potential

Lasiana Beach also has the cultural potential of the socio-cultural life of the local community that is unique and can be used as a tourist attraction, namely the use of palm trees into various handicrafts such as Sasando musical instruments, 
processing water juice extracted from palm trees into sugar. In the morning and evening if tourists visit Lasiana Beach, they can also observe the local community climbing a unique and interesting palm tree.

5. Offering Typical Food of the City of Kupang

Tourists who visit Lasiana Beach can taste the delicious "pisang gepe" (grilled banana) which is a food that is unique to Kupang City (Lasiana Beach). This traditional food can also be eaten with a mixture of liquid brown sugar or water sugar which is also taken and tapped from palm trees.

6. Hospitality of Local Communities

The people around Lasiana Beach are very polite and friendly, always giving greetings and smiles to the visitors at Lasiana Beach. This is what makes the tourists impressed and feel comfortable when visiting this beach.

7. Adequate promotion and Frequently Held Events at Lasiana Beach

Lasiana Beach promotion is quite adequate through online media, such as YouTube, Facebook and Instagram, one of which is the Instagram account "nttpungtapaleuk" which often posts regarding Lasiana Beach. Lasiana Beach promotion is also often done through events held at this beach, such as regional dance festivals, music concerts, construction exhibitions, and other cultural festivals.

\section{(Weaknesses)}

1. Budget Limitations for Management and Development of Lasiana Beach Tourism Objects

Regional budgeting limitations make the development and development of these attractions faltered. Moreover, the NTT Provincial Government is currently focusing on developing 7 buffer destinations in the NTT Province.

2. Inadequate Facilities and Less Attractive Tourist Attraction

The facilities provided at Lasiana Beach are inadequate. There are several broken lopos, hollow trash bins, and damaged children's play facilities and there are no interesting tourist attractions on Lasiana Beach, or that is the only tourist attraction on Lasiana Beach.

3. Unclean Beach Conditions, Wild Animals Roam around the Beach Area and There is Livestock Manure in the Lasiana Beach Area.

There is still quite a lot of rubbish on Lasiana Beach and there are still quite a lot of wild animals that are deliberately released and roam the Lasiana Beach area, which reduces the aesthetics of Lasiana Beach, also cause environmental pollution due to the dung of livestock that are allowed to roam on Lasiana Beach.

4. The existence of Breakwater Levees

The breakwater embankment on Lasiana Beach actually causes mud deposition along the shoreline, which deters the beauty of this beach and makes tourists no longer able to swim freely on this beach

\section{External Factors (Opportunities and Threats)}

\section{(Opportunities)}

1. Develop Lasiana Beach as a Sustainable Tourism Attraction

The development effort is also expected to advance tourism on Lasiana Beach into sustainable tourism and can have a positive impact on the economy of the community and can improve the welfare of the community, promote the culture of the local community, preservation of nature, the environment and other resources at the tourist sites of Lasiana Beach. 


\section{Job Opening for the Community}

With the development of tourism in Lasiana Beach, it will provide opportunities for local people to open businesses on this beach. As the community can sell traditional food to tourists, the community can sell handicrafts to tourists who visit so that it can improve their economy.

3. Enhancing Cooperation with Tourism Players

The Provincial Government of NTT can more aggressively collaborate with tourism actors and investors in building and developing Lasiana Beach, be it repairing damaged facilities, adding facilities on this beach, making tour packages on Lasiana Beach, even building hotels, cafes, or restaurants, to revive the community's economy and revive the tourism industry in the city of Kupang.

(Threats)

1. Tourist Negative Behavior toward Attractions.

Negative behavior of tourists must also be a serious concern for managers of Lasiana beach, because quite a lot of tourists are littering on Lasiana Beach which should be readily anticipated by Lasiana Beach managers.

2. Lack of Cooperation with Investors.

Lack of cooperation with investors in the construction and development of Lasiana Beach has resulted in Lasiana Beach not as advanced and as busy as other tourist beaches, such as tourist beaches in Bali. This should be a serious concern for the NTT provincial government.

3. The Issue of Crocodile Threats.

Many tourists are also reluctant to visit Lasiana Beach because they are afraid of the existence of crocodiles that appear several times around Lasiana Beach.

\subsection{Object Development Strategy and Tourism Attraction of Lasiana Beach, Kupang}

\section{SO Strategy (Strengths and Opportunities)}

1. Some strategies are expected to be able to make Lasiana Beach a sustainable tourism attraction, which are by developing the potential of nature tourism and holding nature-based tourism attractions on Lasiana Beach, developing cultural potential and providing cultural attractions on Lasiana Beach, creating an attractive investment climate especially for the community around, and policies or regulations that benefit all parties, be it for local governments, investors, or the public. Everything is carried out in order to create sustainable tourism on Lasiana Beach that can provide benefits both in terms of environmental, socio-cultural, economic and political aspects.

2. Develop and preserve tourist objects and attractions and improve tourism products and attractions by utilizing the existing potential, such as: marine tourism attractions, water sports attractions, and cultural attractions.

3. Provide counseling and training to the surrounding community to be able to make and sell traditional food, handicrafts, souvenirs and souvenirs to tourists, and provide capital assistance to the surrounding community to open businesses on Lasiana Beach.

4. The Provincial Government of NTT can enhance cooperative relations with tourism actors and investors to invest in building Lasiana Beach to be like the 
tourist beaches in Bali complete with hotels, resorts, restaurants, cafes, attractive tourist attractions and supporting facilities adequate tourism.

ST Strategy (Strengths and Threats)

1. Lasiana Beach management must keep reminding tourists visiting this beach not to damage the beauty of Lasiana Beach and to dispose of trash in the trash cans that has been provided. The need for the addition of trash cans and the presence of boards with interesting writing that reminds tourists to maintain the cleanliness of Lasiana Beach.

2. Convince the public that there are no crocodiles on Lasiana Beach, all of them are just false issues and news. Tourists can safely and comfortably visit and swim at Lasiana Beach.

\section{WO Strategy (Weaknesses and Opportunities)}

1. Provide counseling about the important role of tourism and business opportunities in tourism activities and provide training on local culinary processing, woven cloth, handicrafts and interesting, unique and unique souvenirs to the surrounding community. Moeover, to provide capital for the surrounding community to open a business on Lasiana Beach.

2. Prepare areas with attractive views on Lasiana Beach, and then rent out to tourists for various activities and events. Further, prepare merchandise stalls that are clean, attractive or build culinary markets and snacks with a charming view of Lasiana beach, especially at night, so that economic activities on this beach can live and have implications for improving the welfare of the community.

3. Repair the facilities that have been damaged and add supporting facilities for tourism activities on Lasiana Beach such as children's playgrounds, photo spots, lopo to rest, and increase the number of trash bins on Lasiana Beach and make an appeal board so tourists can dispose of trash in its place, so tourists like to linger on this beach.

4. Inviting the community to discuss their livestock, so that people no longer release their livestock in the Lasiana Beach area. Take firm steps for the people who are still releasing their livestock to roam the Lasiana Beach area.

5. Seeing the urgency of the existence of the embankment on Lasiana Beach, because it only causes mud deposition problems and makes tourists not free to swim on Lasiana Beach.

\section{WT Strategy (Weaknesses and Threats)}

1. To socialize the surrounding community about the importance of tourism development so that the community has an awareness and mindset of tourism in supporting the progress of Lasiana Beach development.

2. The local government must attract as many investors as possible to invest in developing the Tourism industry on Lasiana Beach and in Kupang City. The local government must also prepare regulations and an attractive investment climate and benefit all parties in the development of Lasiana Beach, be it for the local government, investors, and specifically for the community.

\section{CLOSING}

5.1. Conclusion

1. Factors driving the development of objects and tourist attractions in Kupang'sLasiana Beach: the beauty of natural panorama, there are many palm trees, the location is not far from the city center and easy to access, cultural 
potential, offering typical food of the city of Kupang, and hospitality of local communities.

2. The inhibiting factors of object development and tourist attraction of Kupang Lasiana Beach are: budget limitations for management and development of lasiana beach tourism objects, inadequate facilities, and wild animals roam around the beach area; there is livestock manure in the lasiana beach area, less attractive tourist attraction and the issue of the existence of crocodiles.

3. The strategy of developing objects and tourist attraction of Kupang's Lasiana Beach in increasing tourist visits namely: making Lasiana Beach as a sustainable tourism attraction, repairing facilities that have been damaged and the addition of tourist facilities, inviting people to discus about their livestock, see the urgency of the exixtense of the embankment on Lasiana Beach, and convince the public that there is actually no crocodile on Lasiana Beach.

\subsection{Suggestion}

1. The NTT Province's Office of Tourism and Creative Economy as the management of the Lasiana Beach tourism object, as much as possible can increase cooperation with tourism actors or investors in developing Lasiana Beach.

2. The existence of the breakwater embankment must be reviewed its urgency, because the existence of this embankment actually reduces the beauty of Lasiana Beach itself, mud deposition occurs along the shoreline, and causes tourists to no longer be able to swim freely on this beach.

3. The Department of Tourism and Creative Economy of NTT Province must be able to convince the public that the existence of crocodiles on Lasiana Beach is only a mere hoax; there are no crocodiles on Lasiana Beach.

\section{REFERENCES}

[1] Soekadijo, Anatomy of Tourism, Jakarta: Gramedia Pustaka Utama, 2000.

[2] I. M. Adikampana \& S.R. Sanam. "Development of Lasiana Beach Tourism Potential as Sustainable Tourism in Kupang City, East Nusa Tenggara Province”. Journal of Tourism Destinations. Vol. 2, No. 1, 2014, pp. 1-23.

[3] Law Number 10 of 2009 concerning Tourism Article 1 Paragraph 3.

[4] Law Number 10 of 2009 concerning Tourism Article 1 Paragraph 5.

[5] Muljadi, Tourism and Travel, Jakarta: Raja Grafindo, 2012.

[6] Evi Fitriana. "Development Strategy of Kum Kum Tourism Park as Educational Tourism in Palangka Raya City". Journal of Geographical Education at PGRI Palangka Raya University. Vol 2, 2018, pp. 94-96.

[7] Oka Yoeti, Tourism Economics, Jakarta: Kompas, 2008.

[8] Sofjan Assauri, Basic Marketing Management, Concepts and Strategies, Jakarta: Raja Grafindo Persada, 2011.

[9] Sugiyono, Business Research Methods, Bandung: Alfabeta, 2008.

[10] Sedarmayanti, Strategy Management, Bandung: Refika Aditama, 2014. 